\title{
Maternity and Justice in the Early Modern English Court of Chancery
}

Amanda L.Capern a.1.capern@hull.ac.uk

\begin{abstract}
This article is a case study of female litigants acting in the capacity of mother in the English equity court of Chancery between 1550 and 1700. It starts by asking how prevalent mothers were as plaintiffs and defendants in Chancery, though the burden of the article is a qualitative analysis of maternal narratives in Chancery pleadings and the use of gendered tropes such as "poor mother." Stepmothers and women acting in loco parentis - aunts, grandmothers, and godmothers - have been included to reflect the full range of women who acted in a maternal role in early modern society and explain how they were portrayed, sometimes through a querelle des femmes lens. The different legal strategies of mothers (and their lawyers) are examined in detail and the question of the "female voice" in the archives is addressed. The intention is to demonstrate how social and legal maternal identities were used to produce strategic storytelling by mothers and their lawyers in a rhetoric that they hoped would advantage their cases. More broadly, the article addresses questions about the structural connections between law and society, especially the construction of social identity and the habitus and doctrine of equity.
\end{abstract}

This article forms a case study of women acting in the capacity of mother in the early modern English court of Chancery to explore how women pursued and negotiated justice and experienced its limitations. ${ }^{1}$ It starts by asking how prevalent mother-litigants were as plaintiffs and defendants in Chancery between 1550 and 1700, using some quantitative data. However, the burden of the article is a qualitative analysis of the Chancery pleadings of women acting as mothers. Stepmothers and women acting in loco parentis - aunts, grandmothers, and godmothers - have been included in the category of "mother" to reflect the norm that proxy mothers also acted in maternal roles for children in early

\footnotetext{
${ }^{1}$ Amanda L. Capern is a senior lecturer at the University of Hull, Hull, East Yorkshire. She thanks the two anonymous reviewers and the editors of this special issue for acute suggestions and feedback on this article.
} 
modern English society. ${ }^{2}$ The interest is in the tropes associated with maternity - in the semiotic sense - and how these informed a maternal language in equity, translating into particular rhetorical strategies available to maternal plaintiffs and defendants. How were women's (and children's) narrated emotions and stories articulated to make a persuasive legal case in Chancery? Which norms of motherhood were chosen to intersect with the language of equity when seeking redress?

Chancery was an institutional arm of early modern English state governance. It was deeply involved in community affairs, offering arbitration in disputes over money and property and issuing orders to settle the debts of litigants. Chancery masters and clerks sometimes managed estates that belonged to those members of society declared "lunatic," as well as some estates that were in trust or catastrophically in debt. Justice in Chancery originated—at least in theory—in the prerogative powers of the monarch. In practice the court grew out of the medieval cancellaria and the lord chancellor acted as the queen's or king's proxy to exercise the monarch's conscience. ${ }^{3}$ The dogma of equity was that it intervened when no remedy could be found at common law. For this reason, the court generated very specific forms and terms of reference, as will be seen. Chancery was therefore a court of process. It operated a set of rules that were considered distinct from law while (theoretically) "following law." 4 Procedures were relatively simple, if not cheap. A bill of complaint was lodged by the plaintiff (or plaintiffs) that the defendant (or defendants) was required to answer upon subpoena within a few days. Everything was conducted in English. Many cases were resolved quickly after the bill. ${ }^{5}$ Yet by

\section{${ }^{2}$ Barbara J. Harris, English Aristocratic Women: Marriage and Family, Property and} Careers (Oxford, 2002); Lyndan Warner, ed., Stepfamilies in Europe, 1400-1800 (London, 2018).

${ }^{3}$ John Baker, An Introduction to Legal History (Oxford, 2000), 97-100, 259.

${ }^{4}$ F. W. Maitland, Equity: A Course of Lectures, 2nd ed. (Cambridge, 1969), 1, 107-10, 147, 153.

${ }^{5}$ Bills in Chancery could be denied by demurrer or, if answered, supplemented by a replication and a rejoinder, with or without collection of witness depositions to a set of interrogatories. Orders and decrees of the lord chancellor were occasionally enrolled on request (and payment) of litigants. 
the end of the seventeenth century, some family cases in Chancery were as protracted as Charles Dickens's imaginary invention of Jarndyce v. Jarndyce in Bleak House.

Chancery cases were commonly part of wider family dramas over property that often pulled in women. When the nineteenth-century antiquarian George Robert Waterhouse documented all of his family's cases in Chancery between 1509 and 1666, he found dozens of ancestral litigants, many of them female. ${ }^{6}$ They included Priscilla Stephens, who sued for the return of her adult daughter's jointure money in 1613 because there was "nothing left to live upon." ${ }^{.7}$ It was not unusual for early modern families to be embroiled in interconnected lawsuits that spilled between Chancery, the common law courts, and the church courts, and emotions could run intensely high in families during these litigious squabbles. Swapping from defendant to plaintiff was not an uncommon tactic. So although some of the historiography on family, kin, and community litigation has stressed the role of the law courts in mediating community disputes and encouraging reconciliation, a number of historians including Tim Stretton have more recently argued that family litigation could be vicious, strategic, and deeply damaging. ${ }^{8}$ Suits and countersuits of family litigation in Chancery meant that the

\footnotetext{
${ }^{6}$ The National Archives (hereafter TNA), PRO30/27/16, George Robert Waterhouse Papers and Collections: Proceedings in Chancery (1509-1666).

${ }^{7}$ TNA, PRO30/27/16, George Robert Waterhouse Papers and Collections: Proceedings in Chancery, 22 April 1509-23 March 1622, fols. 261-62 (TNA, C 2/JasI/S38/13 Stephens v Waterhouse, 9 October 1613). Mothers of adult children in Chancery were not uncommon and prove the point that parents continued to care for children into adulthood. See Elizabeth Foyster, "Parenting Was for Life, Not Just for Childhood: The Role of Parents in the Married Lives of their Children in Early Modern England," History 86, no. 283 (July 2001): 313-27. ${ }^{8}$ Craig Muldrew, "The Culture of Reconciliation: Community and the Settlement of
} Economic Disputes in Early Modern England," Historical Journal 39, no. 4 (December 1996): 915-42; Alexandra Shepard, "Litigation and Locality: the Cambridge University Courts, 1560-1640," Urban History 31, no. 1 (May 2004): 5-28; Tim Stretton, "Written Obligations, Litigation and Neighbourliness, 1580-1680,"” in Remaking English Society: Social Relations and Social Change in Early Modern England, ed. Steve Hindle, Alexandra Shepard, and John Walter (Woodbridge, 2013), 189-210; Christine Churches, "False Friends, 
original insults, rumors, and accusations at home made a journey from orality and private written communications into a legal language and process that adapted and exaggerated destructive stories, causing further damage and outbursts of more rumors and vitriol back home. ${ }^{9}$

The participation rates of women in the law courts have received some attention, and it has been shown that female litigants were more prevalent in the equity courts than in the common law courts, though their presence in equity courts was almost certainly lower than in the church courts. ${ }^{10}$ However, establishing the prevalence of "mothers" - as one category of woman in Chancery—is not straightforward. The social and familial categories of "mother" (and proxy mothers such as "stepmother," "godmother," and so on) have not been systematically employed as labels or tagging in archival cataloguing. Searching the free-text descriptions of catalogue data for use of the term "mother" between 1550 and 1700 uncovers only a tiny number. ${ }^{11}$ Conducting a quantitative analysis of the fully calendared samples for 1627 and 1685 done by Henry Horwitz and Charles Moreton provides a more accurate picture. The methodology for this current paper was to read the entire

Spiteful Enemies: A Community at Law in Early Modern England," Historical Research 71, no. 174 (February 1998): 52-74.

${ }^{9}$ See Amanda L. Capern, "Rumour and Reputation in the Early Modern English Family," in Fama and Her Sisters: Gossip and Rumour in Early Modern Europe, ed. Heather Kerr and Claire Walker (Turnhout, 2015), 85-114.

${ }^{10}$ Emma Hawkes, ““[S]he will . . . Protect and Defend her Rights boldly by Law and Reason ... ': Women's Knowledge of Common Law and Equity Courts in Late-Medieval England," in Medieval Women and the Law, ed. Noël James Menuge (Woodbridge, 2000), 145, 147-48, 151; Maria Cioni, Women and Law in Elizabethan England with Particular Reference to the Court of Chancery (New York, 1985); Tim Stretton, Women Waging Law in Elizabethan England (Cambridge, 1998).

${ }^{11}$ The data is from a Microsoft Access database created by the author from catalogues of the Chancery series C1-C11 (1558-1758) for a book project, Going to Chancery: Family, Law and Society in England, 1550-1750, supported by a Leverhulme Trust Fellowship, 2019-20. Thanks are due to Liz Hore (Legal Records archivist) and Dr. Amanda Bevan (head of Legal Records, TNA) for access to this catalogue data in a useable form and for offering invaluable expertise and advice for the project. 
calendared descriptions of the cases for 1627 and 1685, identifying all suits involving the rights of children to property in which a woman was actually acting in her capacity as a mother or proxy mother. Out of all the 285 Chancery cases in 1627, just over 8 percent involved litigants who can be identified in the role of mothers/proxy mothers. A rise in maternal litigation is indicated by the 16 percent seen in the 250 cases in $1685 .^{12}$ This increase is perhaps not surprising. Amy Erickson calculated that the proportion of female plaintiffs in Chancery rose from 17 percent to 26 percent between 1613 and 1714, a finding broadly confirmed by Charlotte Garside's work on women's cases in Chancery for Yorkshire between 1670 and $1700 .{ }^{13}$ Yet questions remain. How does maternal litigation compare with overall female litigation in Chancery? What was the balance between maternal plaintiffs and defendants over time? Again, analysis of the calendared Chancery cases for 1627 and 1685 provides answers. In 1627 just under 40 percent of the cases involving female litigants had a mother or proxy mother in the role of principal litigant (either central plaintiff or defendant), whereas by 1685 the proportion had risen to 90 percent. ${ }^{14}$ This suggests a major shift toward litigation involving the property of children (legal "infants" and adult children). Furthermore, whereas only about a quarter of the mothers/proxy mothers were defendants in 1627, by 1685 they made up more than half of all female defendants. ${ }^{15}$

In short, the levels of maternal litigation in Chancery increased as a proportion of the whole,

${ }^{12}$ Respectively, twenty-four cases and forty cases. All calculations are those of the author using Henry Horwitz and Charles Moreton, Samples of Chancery Pleadings and Suits: 1627, 1685, 1735 and 1785, List and Index Society 257 (Richmond, UK,1995), 1-182.

${ }^{13}$ Amy Erickson, Women and Property in Early Modern England (London, 1995), 114-15; Charlotte Garside, "Women in Chancery: An Analysis of Chancery as a Court of Redress for Women in Late Seventeenth Century England" (PhD diss. [AHRC Collaborative Doctoral Project], University of Hull/TNA, 2019).

${ }^{14}$ Using Horwitz and Moreton, Samples, 1-182.

${ }^{15}$ Horwitz and Moreton, Samples, 1-182. See Christine Churches, "Putting Women in Their Place: Female Litigants at Whitehaven, 1660-1760," in Women, Property and the Letters of the Law in Early Modern England, ed. Nancy E. Wright, Margaret Ferguson, and A. R. Buck (Toronto, 2004). 
and women acting as mothers/proxy mothers became a more significant feature of the court.

However, little is known about who they were, why they were in court, and what stories were told about their experiences. Maternal litigation commonly involved widows. Married mothers operated under the legal restrictions of coverture, and the lone married mother in court — especially one who had no letter of attorney from her husband—was very rare. ${ }^{16}$ Many of the women acting in their capacity as mother did not act alone. Mothers, stepmothers, and the occasional proxy mother were in Chancery for a whole variety of reasons that generated a panoply of stories. The actual experience of being a mother/proxy mother in Chancery, therefore, cannot be universalized, though there are some patterns generated by the legal matters at hand around jointure/dower, women's dowries being redirected from their natal families into a husband's family estates, and women's role as guardian of children in protecting those estates from profiteering "waste." It should also not be assumed that mothers in Chancery litigated just to maximize the return for their children-some wanted money back for their children, and others wanted it back from them. Anne Mayo's case, outlined in a tiny bill of 1587, was altruistic: she was offering to pay a mortgage to secure the return of gavelkind lands in Kent "of very greate value" for her sons. ${ }^{17}$ By contrast, Richard Sikes's mother asked that he "repay the money laid out on him" when he was a minor. ${ }^{18}$ It was also not uncommon for mothers to find themselves caught between the interests of several children. In these cases, litigation could drag on for

\footnotetext{
${ }^{16}$ Bronach Kane and Fiona Williamson, eds., Women, Agency and the Law, 1300-1700 (London, 2013); Wright, Ferguson, and Buck, Women, Property, and the Letters of the Law; Margaret R. Hunt, “The Sailor's Wife, War Finance, and Coverture in Late SeventeenthCentury London," in Married Women and the Law: Coverture in England and the Common Law World, ed. Tim Stretton and Krista Kesselring (Montreal, 2013); Barbara J. Todd, "Written in Her Heart: Married Women's Separate Allegiance in English Law," in Stretton and Kesselring, Married Women and the Law.

${ }^{17}$ TNA, C2/Eliz/M90/50 Chancery: Bill in Mayo v Cobham and Paramor, Anne Mayo, Thomas and Francis Mayo (infants), 26 January 1587.

${ }^{18}$ TNA, PRO 30/27/17 George Robert Waterhouse Papers and Collections: Proceedings in Chancery, 10 May 1622-2 May 1650 and Bills in Chancery 1650-1660, fol. 408 (TNA, C10/463/153 Waterhouse v Sikes).
} 
years in suits and countersuits in which a mother might appear for both sides. This happened to Frances Thompson in 1700. Her eldest son was sued by her five daughters and four younger sons, all of whom were owed $£ 1,000$ portions. In the end she relinquished her jointure rights to ease her eldest son's burden and retreated from the legal fray. ${ }^{19}$

Women and their lawyers employed the language of maternity in Chancery in numerous ways. First, they used forms and combinations of words that added adjectival stress emphasizing weakness and vulnerability. "Poor" was one adjective, "distressed" another. Elizabeth Saintclere's testimony of 1597 described her as being "yr poore and dayly oratrix." To reveal her maternity, a reference was added to "her poore distressed children infants." 20 The power of these words lay in what the anthropologist James Scott would call the "weapons of the weak." ${ }^{21}$ Commenting on the habitus of the equity Court of Requests, Liam Meyer categorizes these linguistic tactics as "the rhetorical modes and micro-genres it [the court] wanted to hear; carefully articulated pleadings for mercy, not demands for justice between social equals." ${ }^{22}$ The words were designed to protest bad treatment by oppressors, and so they needed to establish inequalities in relation to the defendant(s). Justice in equity, then, worked in direct relationship with revealed differences of circumstance between litigants.

However, the "weapons of the weak" in Chancery were common to male as well as female litigants and were not used by mothers uniquely. What mothers and their lawyers could do- and did - was layer other topoi of maternity on top of the linguistic construction of the "weak oratrix" to signal the emotional distress of a mother, such as "poor mother" or "utterly ruined mother."

${ }^{19}$ TNA, C 5/284/101 Chancery: Bill in Thompson v Thompson, Mary, Susanna, Isabella, Arabella and Elizabeth Thompson, 20 July 1700.

${ }^{20}$ TNA, C 2/Eliz/S19/61 Chancery: Bill in Saintclere v Ford \& Myles, Elizabeth Saintclere, 8 November 1597.

${ }^{21}$ James Scott, Weapons of the Weak: Everyday Forms of Peasant Resistance (New Haven, 1987).

${ }^{22}$ Liam J. Meyer, “'Humblewise': Deference and Complaint in the Court of Requests," Journal of Early Modern Studies 4 (2015): 261-85, at 275. 
Importantly, they used the charged word mother. Female litigants and their counsel also turned to other expressions that might amplify a mother's plight as she struggled to meet society's expectations about her protective role toward children. One key rhetorical tool in this creation of a maternal narrative was the absence of the caring husband and father. The strategy drew upon the power of the social paradigm of the early modern "household" found in domestic and marital governance manuals such as Dod and Cleaver's A Godly Forme of Household Government. If the mother stood alone, outside of the normal protections that she should expect from a dutiful patriarch, this offered an available rhetoric that might pay dividends in court. So Elizabeth Saintclere's bill of complaint added to "yr poore and dayly oratrix" the story that her husband had relinquished her child's inheritance to fraudulent strangers while in prison because of "grief and sicknesse" that made him "very weake and feeble both in mind and bodye."23

Accusations of fraud and the betrayals of early modern ideals of honor and "friendship" could also be leveled at women. ${ }^{24}$ However, the powerful cultural construction of men's homosociality meant that stories about its breakdown became a very specific form of maternal testimony in the institutional space of Chancery. Breaches of male "friendship" became dialogically entwined with ideas about equitable remedies for mothers and children. In 1595 Mary Merevall and her sons brought a bill of revivor against men whom she accused of taking advantage of her husband in his "great simplicyte" to rob "his wyffe and family" of inheritance. ${ }^{25}$ Constant repetition of her husband's "simplicyte" drove the legal testimony. In a replication of her original bill, she called the defendants'

${ }^{23}$ TNA, C 2/Eliz/S19/61 Chancery: Bill in Saintclere v Ford \& Myles, Elizabeth Saintclere, 8 November 1597.

${ }^{24}$ Capern, "Rumour and Reputation," 114.

${ }^{25}$ TNA, C 2/Eliz/M13/36 Chancery: Bill in Merevall v Thorley, Warren and Barnes, Edmund Merevall, 20 January 1587 and Bill (Revivor), Mary Merevall and Thomas Merevall (infant), 13 June 1595. 
answers a "slanderous" attack on the widow of "a very simple man." ${ }^{26}$ In 1698 Mary Taylor and her lawyers used a similar but related tactic. They portrayed her late husband as a weak man who gambled and ran up huge debts before colluding with male friends and kin to sell her jointure lands and ruin their son's estate. When her husband and a coterie of his "friends" allegedly burned the marriage settlement, it was "in breach of the trust in them . . reposed" and—worse still—it happened "without the consent of ye Oratrix ... all which transacons happened whilest your Oratrix was under Coverture and in ye infancy of ye Orator [her son] and without her consent or privity." 27

The linguistic power of maternal language in Chancery lay in the particularity of the weakness of mothers. Mothers could usefully and very easily be depicted in bills, answers, and depositions as the subordinate party in marriage and in their social relationships with other male kin because of inequitable gender norms and the institutional structuring of marriage and family. ${ }^{28}$ The process of writing the legal narrative, then, was one of linguistic layering in the text, to transform the ungendered "weak orator" into the more specific maternal figure to invoke equity's dispensation of justice in the case of mothers. The tiny, inexpensive bill lodged by Margaret Odams in 1652 demonstrates this linguistic construction and layering at work. On behalf of herself and her ten-yearold twins, the bill spoke emotionally of the "undoinge of your poore distressed orators," but the court was also to learn of her plight as a widow and single parent after the death of her husband during the civil wars. The disadvantage of the absent man was added to by the dereliction of male duty shown by the grandfather of the boys when he failed to pay them a legacy of $£ 10$, even though they were "the

${ }^{26}$ TNA, C 2/Eliz/M13/36 Chancery: Bill (Revivor) in Merevall v Thorley, Warren and Barnes, Mary Merevall and Thomas Merevall (infant), 13 June 1595 and Replication (of Bill of Revivor), Mary Merevall and Thomas Merevall (infant), n.d. [1595?]. ${ }^{27}$ TNA, C 6/341/23 Chancery: Bill in Taylor and Taylor v Bridgewater, Taylor, Rickards and Knill, Mary Taylor and Nicholas Taylor (infant), n.d. May 1698.

${ }^{28}$ I am grateful to Tim Stretton for sharing his essay for this special issue with me ahead of publication. It sharpened and informed my thinking about subject relationships in Chancery cases. 
natural children" of his dead son who stood directly in his "name and blood." ${ }^{29}$ In this way, referencing maternity and weakness in direct relation to a father-in-law who held the property and the power appealed for justice by throwing a light on his disregard for the "natural" order of male lineage. The language that brought maternity together with the idea of justice was often, then, constructed in relation to men.

Chancery pleadings of mothers also embedded the legal validation of their authority as guardians of children under the age of twenty-one (or as a prochein amy / "next friend").

Strengthening this strategy was the social power that emanated from a woman's culturally constructed maternal role as caretaker of the family in body, soul, and memory. ${ }^{30}$ Put simply, the legal rhetoric could shift so that mothers were not simply stricken wives and widows. The positive elements of their performance of maternal duties could be accentuated while pointing to the deficiencies of their adversaries in the court. The complaints and answers observed certain rules of maternal performance that fashioned speech acts according to the strategic legal needs of the case in the arena of Chancery and in direct relation to its jurisdiction. The words used were not necessarily the same as those that could "prove" a woman's character in the church courts or other civil courts, as found by Alexandra Shepard and Laura Gowing, because the cases were about different things. ${ }^{31}$ There was specificity to

${ }^{29}$ TNA, C 7/255/10 Chancery: Bill in Odams v. Odams, Margaret Odams, Mathew and Mary Odams (infants), 24 June 1652. In 2005, £10 was equivalent to $£ 800$ (TNA, Historical Currency Converter).

${ }^{30}$ See James Daybell, "Gender, Politics and Archives in Early Modern England," in Gender and Political Culture in Early Modern Europe, 1400-1800, ed. James Daybell and Svante Norrhem (Oxford, 2016), 25-46.

${ }^{31}$ See Alexandra Shepard, Accounting for Oneself: Worth, Status and the Social Order in Early Modern England (Oxford, 2015); Laura Gowing, Domestic Dangers: Women, Words and Sex in Early Modern London (Oxford, 1996); Alexandra Shepard, "The Worth of Married Women Witnesses in the English Church Courts, 1550-1730," in Married Women and the Law in Premodern Northwest Europe, ed. Cordelia Beattie and Matthew Frank Stevens (Woodbridge, 2013), 191-212; cf. Laura Gowing, “"The Manner of Submission': Gender and Demeanour in Seventeenth-Century London," Cultural and Social History 10, 
the language of maternity in Chancery, and women acting in their capacity as mothers were represented as possessing heartfelt and self-sacrificing motherly intentions. ${ }^{32}$ The court testimony needed to show that a mother wanted to be able to care for her children better than current circumstances allowed, while emphasizing that she was a "poor supplicant" who had done all that she could for her children.

Women acting as mothers brought to Chancery a weighty social baggage. Patricia Crawford has commented, "Childbirth was the female rite of passage par excellence." ${ }^{33}$ More than 90 percent of elite married women became mothers in the late sixteenth century, and although fertility rates dropped over the period, the hegemonic social meanings of motherhood stayed the same. Women were socialized into (and self-defined as) taking on a lifetime of responsibility for the spiritual and temporal welfare of their children. ${ }^{34}$ If narrations of motherhood in the records of Chancery are thought of as a form of mediacy or mittelbarkeit (the conduit of communicability of a story), then the narrator (and her co-writers) told stories in rhetorical construction and performance that reflected the normative world for the listener. ${ }^{35}$ Biological mothers, in Chancery in particular, could be represented as having

no. 1 (2012): 25-45; cf. Cordelia Beattie, “"I Your Oratrice': Women's Petitions to the Late Medieval Court of Chancery," in Kane and Williamson, Women, Agency and the Law, 1300$1700,17-29$.

${ }^{32}$ See Wolfgang Zierhofer, "Speech Acts and Space(s): Language Pragmatics and the Discursive Constitution of the Social," Environment and Planning, 34 (2002): 1355-72.

${ }^{33}$ Patricia Crawford, "The Construction and Experience of Maternity in Seventeenth-Century England," in Women as Mothers in Pre-Industrial England, ed. Valerie Fildes (London, 1990), 11, 21.

${ }^{34}$ Barbara J. Harris, English Aristocratic Women; "Defining Themselves: English Aristocratic Women, 1450-1550," Journal of British Studies 49, no. 4 (October 2010): 73452, figures at 739; Barbara J. Harris, “Aristocratic and Gentry Women," History Compass 4, no. 4 (2006): 668-86.

${ }^{35}$ Franz Karl Stanzel, A Theory of Narrative (Cambridge, 1982), 4, 146, 154. See also D. A. Miller, Narrative and Its Discontents: Problems of Closure in the Traditional Novel (Princeton, 1981), 157-58. 
the infant peeking out from behind the mother's body, vulnerable and deeply in need of protection. The child's voice could be an emotionally very powerful one when used in a bill. Indeed, it was not uncommonly deployed as the "oratrix" narrator in a legal suit, even if the child was in reality too young to be an orator at all. The infant Barbara Hobson is a case in point. A bill of complaint in 1679 described her as "an infant of tender years," yet she voiced her evidence that she did not know if her late uncle left a nuncupative will to favor his widow over her to inherit his estate. This baby stated firmly that she was the "heir at [common] law." 36

Ventriloquized voices were a legal "fiction" in court records created by lawyers and family members pursuing or protecting a child's interests. Their claim was to a larger moral "truth." In the Hobson case, the ventriloquized voice of the female baby came into dialogue with the male ghost voice of the dead uncle in his widow's answer to Chancery. The uncle was heard to say that he wished to be returned "to Mother Earth ... in the place where my child [a male heir] was buried." ${ }^{37}$ The dead testator's widow and her lawyer no doubt hoped that the voice of a patriarch, speaking from the family grave that he shared with a child of "name and blood," might lend some greater evidential weight to her claims against another mother acting for a live child.

Arlette Farge has observed that court records leave the reader with the "profound feeling of tearing away a veil." 38 The impossible voice of a live baby in legal dialogue with a dead man exposes the raw emotions of the two mother-litigants in Chancery. Yet the historian needs to be mindful of textual tropes that were common at the time. Dialogues with ghosts were a well-used literary device in political pamphlets from the Cromwellian republic onwards. Indeed, Oliver Cromwell himself (along with John Lilburn, John Bradshaw, a host of regicides, and the Rump Parliament) was a frequent spectral visitor to "talking" political pamphlets post mortem. ${ }^{39}$ Ghosts entered cultural discourse and

\footnotetext{
${ }^{36}$ TNA, C 5/500/16 Chancery: Answer in Hobson v Hobson, Barbara Hobson (infant) and Emma Hobson, 22 March 1679.

37 TNA, C 5/500/16 Chancery: Bill in Hobson v Hobson, Elizabeth Hobson, 15 March 1679.

${ }^{38}$ Arlette Farge, The Allure of the Archives (New Haven, 2013), 4-8.

${ }^{39}$ See, for example, Bradshaw's Ghost being a Dialogue between the said Ghost, and an apparition of the Late King Charles (London: s.n., 1659).
} 
the political lexicon to comment on what ought to be done in the present. The dead uncle in Chancery did just this. His voice was folded into his widow's maternal language of pain, love, and grief for him and their dead child. It was the classic Renaissance use of prosopopoeia to add value to the words of another communicator. Thus, in the legal imaginary, Barbara Hobson's uncle rose from the grave in a scene reminiscent of Greek tragedy.

The concept of "name and blood" represented a double-edged sword for mothers in Chancery. It could work against a female litigant because of gender connotations and social hierarchy—in the end, she was not the patriarch. But equally, it could be put to good rhetorical use when a mother and her lawyers conjured up the men to whom she and a child were related. Typical of such a positive use is that found in Mary Blanchard's case of 1620. Her bill was constructed in such a way as to protect her son's inheritance against the claims of other kin members by arguing that the land should "continue in his [the grandfather's] name and blood." ${ }^{40}$ Similarly Elizabeth Tomes's complaint of 1660 used the rhetorical strategy of accusing her father-in-law (who was actually dead) of being "utterly ignorant of the law" and allowing his second wife to scarper with a lease "not long after he was dead and buryed." In this instance, the maternal weapon of the weak was the man's foolishness and dereliction of duty toward "his right heires forever." "Right heires" referred to Blanchard's late husband who was the "first-born" son. ${ }^{41}$ The bill of complaint co-opted the legal persuasive (and power) of primogeniture. Primogeniture was a common law doctrine that was normally something that worked against women, but used rhetorically like this in Chancery by a woman in her role as mother, it was repurposed to suit her legal needs in a specific case relating to a husband or male child.

The intersection that took place between the maternal language seeking justice in equity and the strategic procedural needs of evidence in the court can be seen in two narratives that regularly had

\footnotetext{
40 TNA, C 2/Chast/B28/17 Chancery: Bill in Blanchard v Blanchard, Mary Blanchard and Thomas Blanchard (infant), 25 November 1620 and Answer, Ann Blanchard, 18 January $1620 / 1$.

${ }^{41}$ TNA, C 7/446/69 Chancery: Bill in Tomes v. Wharton, Elizabeth Tomes and Anthony Tomes (infant), 25 June 1660 . The equivalent of $£ 30$ is about $£ 2,000$ of spending power today.
} 
to be told in Chancery. The first of these was plaintiffs' construction of their cases around the "confederacy" or underhand and collective behavior of defendants as the latter tried to defeat "poor orators." A second common component of a Chancery case was a request for "discovery," built around the loss, destruction, or withholding of documentary evidence needed by the plaintiff to prove right and title. ${ }^{42}$ A maternal language could be woven together for rhetorical appeal around these two procedural requirements. Anne Kendall complained in 1591 that a "combinacon" of men were plotting against her child, and it was "purposely done to defette ... the Infante ... [and] thruste your poore or[atri]x \& the younge Infante out of possession ... [to] the utter undoing of them both against all right equity \& good conscience." 43

Similarly Katherine Edwards and her yeoman son Robert complained in 1580 that he had been denied his inheritance of demesne lands in Shropshire that had been promised for the life use of his mother "ad ostium ecclesiae [at the church door]" by deceitful "confederating" kin who conveyed to themselves "secret and fayned estates of inheritance ... without recorse either had to lawe conscience or honest dealings." 44

Confederacy was not a gendered concept in equity, but its portrayal could be. In Green v Mawson and Stoakes, a mother's case that ran for a full three years beginning in 1685, Mary Green lodged a bill of complaint on behalf of her four children against John Mawson and Mary Stoakes. Mawson was trustee of the children's estates after her husband had been killed during the civil war. Green sought to discredit Mawson for allegedly “hiding” or losing her husband's will and employing Stoakes, a woman described as "a pretended hired Servant or Nurse." Green's bill first accused the defendants of "confederacy" through fraudulently taking into "custodyes or possessions all the said

\footnotetext{
${ }^{42}$ See Dennis R. Klinck, Conscience, Equity and the Court of Chancery in Early Modern England (Farnham, 2010), 194-45.

${ }^{43}$ TNA, C 2/Eliz/K1/53 Chancery: Bill in Kendall and Kendall v Wright, Rogers and Whitney, Anne Kendall and John Kendall (infant), 12 May 1591.

${ }^{44}$ TNA, C 2/Eliz/E1/39 Chancery: Replication in Edwards v. Edwards, Robert Edwards and Katherine Edwards, 12 October 1580.
} 
bonds bills noates [and] writings" of her very aged father-in-law. ${ }^{45}$ The rhetoric was then intensified by accusing Stoakes of taking advantage of a man "thin by much weakness and decayed . . in his memory Judgment and understanding. ${ }^{, 46}$ Her own maternal care stood usefully in contrast to that failure of nurture in the other woman. This mother's bill claimed that she had reposed "great trust" in Mawson — a man who ought to have been trustworthy by virtue of his gender and position — and had become "a great sufferer thereby." Chancery litigants from all social categories used similar phrases, but these words took on particular intensity for this mother because her suffering was caused by the vicarious pain she felt for her four children.

The second component of many Chancery cases was a request for missing documents, especially for women whose access was restricted by the workings of coverture. Again, while the strategy of building a rhetorical case around lost "writings" was not unique to mother litigants, maternity could be highlighted in stories about secrets and lies that hid "the truth" so that a "poor distressed mother" could be represented as bamboozled and defeated by the subterfuge. Bills of complaint contained elaborate stories about hidden chests, stolen keys, and locked boxes. When inserted into narratives containing details so particular about a mother's experience, these are the stories that can seem the least plausible relation of "facts." The bill lodged by and for the mother of five-year old Richard Cockes claimed that his title deeds were "in a boxe locked or bagge sealed up. ${ }^{\prime 47}$ Versions of the story were repeated in case after case. Katherine Edwards's bill was another that claimed that proof of her son's rights lay in a "bagge boxe sealed or shifte locked."

${ }^{45}$ TNA, C 6/252/29 Chancery: Bill in Green v Mawson, John Green, Edmund Green, Mary Green, Dorothy Green (all minors) and Mary Green, mother and "Next Friend," 23 October 1685 .

46 TNA, C 24/1099 Chancery: Interrogatories in Green v Mawson, Mary Green, and John Green, Edmund Green, Mary Green, Dorothy Green (all minors), n.d. April 1686.

47 TNA, C 2/ JasI/C26/63 Chancery: Bill in Cockes, and Cockes v Cockes, Goosey and Coles, Elizabeth Cockes, 4 May 1617.

48 TNA, C 2/Eliz/E1/39 Chancery: Replication in Edwards v. Edwards, Robert Edwards and Katherine Edwards, 12 October 1580. 
These formulaic phrases were woven together with the emotions of anguish, sadness, grief, and anxiety to amplify a maternal language of appeal in nearly all mothers' cases, except for those brought by wealthy mothers active in estate management who could not always claim a lack of access to evidence. Elizabeth Burgh's case of 1618 falls into this category. She and her legal counsel accused her estate steward of deceit and fraud committed against her son's inheritance, but the steward insisted that Elizabeth regularly reviewed and signed all estate accounts and arrived at her "owne bargaines" with chapmen when exchanging land leases. ${ }^{49}$ In other words, there was a legal rhetoric of maternity that emphasized the weakness of mothers and their inability to control people and events, but that rhetoric might be of little use to women building their case around competent and active involvement with property and financial matters.

The most accessible and emotionally powerful tool used for the maternal litigant in Chancery was reference to her fertile and lactating body. The case of Johan Barthram in 1644 illustrates how this worked in practice. Barthram was a young mother living with her husband, Thomas, and baby, Elizabeth, in London. Elizabeth was heir to the estate of Nathaniel Troumble of Newcastle. When he died, Johan Barthram became administrator of her child's inherited estate of a house, shop, and about $£ 100$ in chattels. The following story was conveyed to a lawyer by Barthram and her husband, and a bill of complaint was constructed that turned her tale into a highly charged maternal drama alongside the request for the "ayde and favour" of the court: "Yr oratrix Johan having intelligence of his [Troumble's] death ... with the consent of her husband Thomas Barthram wrott a letter unto one Lawrence Reade and his wife who were [with Nathaniel when he died] . . . and thereby intimated unto them that ye oratrix Elizabeth was living." 50

It was recorded that the Reades refused to release to Barthram the title deeds and letters of administration before seeing bodily evidence of the child. In order to satisfy this demand, Barthram, it

${ }^{49}$ TNA, C 2/Jast/B21/38 Chancery: Answer in Brooke and Burgh v Blake, William Blake, 19 November 1618.

${ }^{50}$ TNA, C 2/Chas I/B41/6 Chancery: Bill in Barthram v Reade, Johan Barthram and Thomas Barthram, n.d. 1644. 
was said, then traveled alone during the "troublesome times" of war while Elizabeth was "then sucking at her breast." This mother "travailed and journiede from her house at Woolwich [to Newcastle]" upon the "faire promises" of the Reades that they would shelter her when she arrived. Instead, as it was recalled and recounted later, she found herself "farre from [home] and in a strange place," turned away from the door of the house in appalling need "for want of money in respect of the charge of herselfe and the infant, but they [the Reades] would not supply her needs nor release the letters of administration." At this point in her experience, the story went, Barthram was "enforced to borrow money off some charitable people in those parts dwelling neare" before returning home empty-handed and "utterly remedilesse for reliefe" - unless, of course, she was able to find "reliefe" through the court of Chancery. ${ }^{51}$

Johan Barthram's story was manna from heaven in an equity court. Feeding her baby, traveling over four hundred miles of war-torn countryside, this mother had still been denied the child's rights by complicit adults who "lost" documents and then utterly failed even in their duty of neighborly care. However, for all of its emotional, appeal the bill inevitably raises questions about whose voice is being heard in the archives. The legal testimonies of wives were frequently refracted through a husband's voice of entitlement, and a legal clerk's voice would creep into the telling as well. How much of the story about Johan Barthram's suffering do we actually hear from her? Joanne Begiato has raised this very question about whether or not the "voice" heard in "archival virtual reality" is that of the female litigant or if it represents the heavy hand of the lawyer. ${ }^{52}$ The negotiation for justice by a mother or proxy mother began when she (and, if married, usually a husband) paid a lawyer his fee to construct a persuasive pleading. As lawyers "bridged the gap between crown and subject," this arrangement directly drew women into the ambit of state governance, but the degree to which it empowered women through their voice being heard in a broader political sense is another

51 TNA, C 2/Chas I/B41/6 Chancery: Bill in Barthram v Reade, Johan Barthram and Thomas Barthram, n.d. 1644.

52 Joanne Bailey [Begiato], "Voices in Court: Lawyers or Litigants?” Historical Research 74, no. 186 (November 2001): 392-408, at 392. 
matter. 53 "The I who speaks" in the records, Frances Dolan has recently cautioned, "is often someone else," and testimony in court records is a function of venue and genre; it was produced "collaboratively and conjecturally." 54

Two problems arise to consider. The first is that the language of maternity might be made to carry a weight of emotions that were not provided by the litigant herself. However, the second is that our knowledge that this might be the case could prevent us from listening and really hearing the mother's account about her lived experience. The second may be the worse outcome for historians. One solution is to interpret the collusive words of a lawyer as amplification of the mother's own story and socially constructed maternity. Is it possible that finding multivocality in the court records matters less than one would think? In the Barthram case, husband and lawyer were the coproducers and enablers of a maternal language of persuasion. Certainly Johan's testimony was told at one remove through use of the pronouns her and she throughout the bill. Yet the recounted details about the difficulties of trying to feed an infant through this ordeal seem most likely to have been supplied by the mother herself.

If biological mothers and their lawyers could draw upon embodied maternity to construct a legal rhetoric, then this rhetoric potentially tapped into the moral economy of normative motherhood, which was no more powerfully represented than when a woman was pregnant or nursing a baby. Godly motherhood tracts depicted the pregnant female body romantically, and early modern portraits of mothers projected an über femininity. Thus, maternal bodies became important pieces of evidence in legal narratives that had a highly emotional and gendered baggage attached. ${ }^{55}$ Mary Gee's lawyer

\footnotetext{
${ }^{53}$ See Julie Hardwick, “Women 'Working' the Law: Gender, Authority and Legal Process in Early Modern France," Journal of Women's History 9, no. 3 (Fall 1997): 28-49, at 45. ${ }^{54}$ Frances Dolan, True Relations: Reading, Literature, and Evidence in Seventeenth-Century England (Philadelphia, 2013), 117.

${ }^{55}$ Naomi Yavneh and Naomi Miller, eds., Maternal Measures: Figuring Caregiving in the Early Modern Period (Aldershot, 2001); Kathryn M. Moncrief and Kathryn McPherson, eds., Performing Maternity and Early Modern England (Aldershot, 2007); Karen Bamford and
} 
used her maternal body obliquely in legalese as a direct response to procedural need in Chancery. After her husband's death, Gee brought a bill of revivor in 1679 to pursue her sons' claim to lands in East Yorkshire. The father's original bill had read "heirs," and the lawyer edited this by parenthesis to "children." Even more tellingly, he scratched out "heirs" in some places to insert "issue of her body." ${ }^{56}$ The lawyer's edits reflected the shift in legal status of the guardian complainant: they were her children but his heirs. However, the addition of "issue of her body" took the message further and symbolically inserted an umbilical cord.

Maternal tropes in Chancery relied heavily on the powerful and broadly applied signifiers of "mother" in early modern England. People spoke of the mother church, the mother tongue, mother truth, and mother time. Negatively, as in a querelle des femmes inversion, "the mother," of course, was even a physician's metonym for the uterus. "The mother" medicalized female nature into a negative disruption of the fertile female body whenever it was not physically "with child." Much of the modern historiography on early modern mothers follows the positive signification. It is as if the maternal woman has transhistorical meaning, embodying self-sacrificing, naturalized love toward children of the kind that creates a mystical bond with other women who are/were mothers too. ${ }^{57}$ Certainly Hester Crowe's plea in a bill of 1697 appealed to the sympathy of two female kin members as she and her lawyers claimed she was struggling to survive as a widow with five children. All three women had been left legacies of $£ 500$ that turned out to be paid in clipped money and "putt out upon

Naomi Miller, eds., Maternity and Romance Narratives in Early Modern England (Farnham, 2015).

${ }^{56}$ TNA, C 5/486/5-6 Chancery: Bill in Gee v Hotham and Gee, Mary Gee, Robert Gee and Richard Gee, 21 February 1679 and 29 May 1682; TNA, C 5/85/7 Chancery: Answer in Gee $v$ Hotham and Gee, John Hotham, 28 February 1679; author's emphasis.

${ }^{57}$ Linda Pollock, "Childbearing and Female Bonding in Early Modern England," Social History 22, no. 3 (October 1997): 286-306; Barbara Harris, "Regional and Family Networks: The Hidden Role of Sisters and Sisters-in-Law," in Daybell and Norrhem, Gender and Political Culture, 107-22; Warner, Stepfamilies in Europe. 
single and weaker Securityes." ${ }^{58}$ Crowe's maternal plea to her female kin was that she had virtually no income with which to support her five children. The answer of one of them was as follows: "This Def[endan]t hath heard that some loss thereof might have been prevented had ... Hester Crowe taken her Legacy at the time appointed or consented to an Order of this Court to have had the same Clipt money paid into the Exchequer upon some of the funds there carrying Interest." 59

In other words, in Chancery a mother's testimony might be framed around her plight and the vulnerability of her children to appeal to the bonding of female kin. Equity—as habitus and langue did not exist in a cultural vacuum. However, the language of maternity used by one woman and her counsel did not guarantee anything beyond a statement of the financial facts by other women when they found themselves on opposite sides of a Chancery case, even if a hint of sympathy and empathy can be detected in the detail of the response.

Furthermore, the essence of the bad mother of the inverse stereotypes of popular literature, such as "unnatural mother," "mother devell," "mother of harlot," "Mother Lakeland," and—-the most mercurial of all-"Mother Shipton," all could be drawn upon in Chancery too. ${ }^{60}$ This should not surprise, for two reasons. First, as sociologists point out, hegemonic social ideals create their own opposites. The naturalized good mother produced its own inverse in the social category of bad mother, offering persuasive legal rhetorics both for and against female litigants. Second, English legal procedures were adversarial, and at least two different interpretations of the same events inevitably

${ }^{58}$ TNA, C 6/396/62 Chancery: Bill and Answer in Crowe v Crowe, Lulman and Lulman, Hester Crowe, 15 April 1697 and Elizabeth Crowe, 30 April 1697.

${ }^{59}$ TNA, C 6/396/62 Chancery: Answer in Crowe v Crowe, Lulman and Lulman, Elizabeth Crowe, 30 April 1697.

${ }^{60}$ See, for example, Joan's ale is new or: a new merry medley, shewing the power, the strength, the operation, and the vertue that remains in good ale, which is accounted the mother-drink of England (London, 1680); The lawes against witches . . Also the confession of Mother Lakeland, who was arraigned and condemned for a witch [. . .] (London, 1645); The prophesie of Mother Shipton (London, 1641). 
emerged in any Chancery proceedings that continued beyond the initial bill stage. ${ }^{61}$ As Christine Churches has argued, the idea that courts mediated in family affairs to achieve peaceful reconciliation is invariably thwarted when "false friends" were uncovered "as bad as enemies, even worse ... spiteful enemies." ${ }^{62}$ In querelle des femmes fashion, linguistic layering could work in reverse. The devoted mother as represented (usually self-represented) in court found her opposite in testimonies about the cruel stepmother, the wicked aunt, the greedy grandmother, and so on. Women acting as proxy mothers found themselves particularly susceptible to representation by other litigants (including mothers) as coercive maternal figures who were parasitic on children. ${ }^{63}$ In 1628 , Elizabeth Waterhouse was portrayed by her own younger sister, Dorothy Copley, as well as by friends and neighbors in her natal village, as distinctly unmaternal for withholding her sister's inherited portion of $£ 573$. Waterhouse had acted as a proxy mother/guardian to her sister for sixteen years and felt entitled to some reimbursement out of the family estate. Yet her kin and neighbors depicted her as unnaturally greedy. ${ }^{64}$

Inversions of the norms of good motherhood could also be found in invasions into maternal space. Maternal imposters provided a powerful rhetorical tool to add to the weapon of the weak in a "good" mother's testimony. So Richard Cockes's mother and her lawyer embellished her story by saying that his grandfather "hath lately married a seconde wife beinge a very yonge woeman himself beinge very oulde and haveinge children by her doth nowe labour and goe about to disinherit y[ou]r

${ }^{61}$ Paul Raffield, Images and Cultures of Law in Early Modern England: Justice and Political Power, 1558-1660 (Cambridge, 2004).

${ }^{62}$ Churches, "False Friends, Spiteful Enemies," 52, 70.

${ }^{63}$ See Tim Stretton, "Stepmothers at Law in Early Modern England," in Warner, Stepfamilies in Europe, 91-107.

${ }^{64}$ TNA, PRO 30/27/17 George Robert Waterhouse Papers and Collections: Proceedings in Chancery, 10 May 1622-2 May 1650 and Bills in Chancery 1650-1660, fols.117-18, Waterhouse v Copley, 21 July 1628 (TNA, C 2/ChasI/W76/10; earlier case in 1624 also at TNA, C 2/ChasI/W112/31). See also counter case and depositions at TNA, C 2/ChasI/C 112/23; C 21/W73/1; C 21/C 13/23; C21/C 19/20. 
pore suppli[c]ant." ${ }^{95}$ The youth of the step-grandmother of Richard Cockes was brought into lexical play to demonstrate how she displaced the mother whose child should have been thought of first as "name and blood" in patriarchal descent.

The inversion and invasion rhetoric in maternal pleadings could become very complex if two mothers found themselves in conflict at home and in Chancery. Both litigants could self-represent (and be represented by others) as a "good mother" while accusing their opponent of being a "bad mother." In the Machiavellian struggle over two decades between Margaret Danby and her dead husband's kin network, Margaret went head-to-head with her sister-in-law, Anne Danby ${ }^{66}$ The personal (and financial) spat resulted in bills and answers in which their own and each other's maternal attributes were portrayed on a scale ranging from the Virgin Mary to one of the Gorgon sisters. So what stories from back home were told when these two mothers met - textually speakingin Chancery?

Margaret Danby and her lawyers argued that she had acted as a responsible proxy mother by seizing the children of Anne Danby. The claim was that she had raised them alongside her own son, thereby transforming their fortunes and physical health. Her pleadings portrayed Anne as a negligent "bad" mother who had underfed her own children and allowed them to become filthy in a squalid house. ${ }^{67}$ Anne's testimonies completely reversed the account and upended the maternal paradigms. In one deposition Anne was depicted as a deeply loving mother who was so devoted to her children that when they were forcibly taken from her the neighbors in the street were crying at the injustice. The tactic taken by Anne, her kin, and the lawyers was to destroy the reputation of Margaret Danby by focusing on the nurturing qualities that could be expected in a mother. Margaret was described as being an "inhuman Lady" who took Anne's husband "in her power" before giving him enough money

${ }^{65}$ TNA, C 2/ Jast/C26/63 Chancery: Bill in Cockes, and Cockes v Cockes, Goosey and Coles, Elizabeth Cockes, 4 May 1617.

${ }^{66}$ For a narrative account reconstructed from Chancery records at TNA and Danby family papers at the North Yorkshire Record Office (NYRO) of the whole family litigation and Margaret Danby's guardianship of her son's estate, see Capern, "Rumour and Reputation." ${ }^{67}$ Family Papers: Copy of Pleadings, Danby v Danby, 1675, NYRO, ZS*. 
to drink himself to death. The theory put forward was that Margaret's "children died so fast, but one remaining alive (and he very infirm)" that she had designs on Anne's healthier offspring. ${ }^{68}$ Some of this testimony is worth quoting at length. It contains very direct imputation that the family matriarch-Margaret Danby—should have acted more like a proxy mother to all of the children and exercised the care and emotional bonding expected between women of the same kin network:

She removed us to Beedall [Bedale] to a most wretched house ... [with] no chamber in it ... which moisture bred frogs $\&$ toads ... which came crawling to me to ye fireside $\&$ crept up on my bed [and] this old building swarmed with rats \& mice ... Ye first night I lodged in this dismal place (whither I was brought great with child) ye extremity of my grief forced from me so much blood \& tears . . I I knew not which ran down fastest ... which were much augmented by the sharp taunts I received from this insulting sister who came often to torment me ... [yet] she would gladly have made ye world believe [this treatment] was out of her own great bounty \& goodness but as Solomon saith ye tender mercies of ye wicked are cruelty ${ }^{69}$

At one point Anne Danby's twice-told tale in Chancery makes reference to Margaret Danby being an "unnatural mother" who might even have been homicidal toward her own children — the death of Margaret's last surviving child by a fall from a horse was retold as somehow mysterious and unlikely. ${ }^{70}$ Added to this was the failure of Margaret, as a sister-in-law, to provide an adequate lyingin chamber and act appropriately as a "godsib" during the birth.

Danby v. Danby rumbled on for as long as the later fictional Jarndyce v. Jarndyce and destroyed family relations and the health and well-being of the litigants as permanently as those in

\footnotetext{
68 "An account of my mothers suffering written under her owne hand" [Copy of Chancery deposition of Anne Danby, 1683], NYRO, OUTFAC 141.

69 “An Account” [Copy of Deposition, 1683], NYRO, OUTFAC 141; TNA, C 22/780/8

Chancery: Depositions in Danby v Danby, 1676-1677.

70 “An Account” [Copy of Deposition, 1683] NYRO, OUTFAC 141; see Capern, "Rumour and Reputation.”
} 
Dickens's tale. Several things can be drawn from the case in relation to mothers in Chancery. First, the quarrel between these two mothers reminds us of Bakhtin's notions of dialogism and "polyphonic truth." Which one-Margaret Danby or Anne Danby—was telling "the truth?" Second, how does "truth" relate to the authenticity of the maternal "voice?" In Danby v. Danby, the surviving personal papers that lend context and do or do not corroborate the stories told in Chancery reveal high levels of involvement by both women in the voicing of their testimonies and the assembly of case papers. One finding of this article, then, is that female "voices" in court may have been ventriloquized, co-opted, or even subverted by husbands, male kin, and "the lawyer's hand," but even so, some women can be heard more loudly than others in the legal archives. The extent of this can most accurately be assessed if enough family and estate papers also survive to allow historical judgments. However, what about the matter of "polyphonic truth"? In some ways, this is the more intractable problem. As soon as layering and reversals occur in Chancery testimonies over the top of social identities such as "mother," it becomes more difficult to trust not so much the authenticity of "voice" but the moral content of the stories being told. The two Danby mothers recounted the same story: it is not exactly fiction that we find in the archive of court records. Instead what we find in this competition for maternal rectitude between two female litigants in their legal testimonies is exactly what the Chancery judges found: that in human relations, "good mothers" and "bad mothers" turn out to be the same people and their stories just two sides of the same coin.

The culturally accepted norms of early modern motherhood were clearly linguistic weapons of the weak in the legal space of the English court of Chancery. Women acting as mothers and their lawyers used layered topoi to describe them as "distressed mother," "poor mother," "loving mother," and so on to articulate and perform (textually) the women's emotional and financial plight while negotiating justice for themselves and their children. Equally, the maternal ideal could be reversed for rhetorical effect. When the focus of a case encouraged a woman to be viewed as a "mother," then the cultural constructions of maternity—good and bad—came into productive dialogue with equity and its central concepts of the "weak orator" and "confederating," secretive, fraudulent opponents.

The broader finding of the article is that textual representations of maternity in early modern English Chancery pleadings demonstrate the structural connections between law and society. 
Chancery, the most dominant equity court by the end of the seventeenth century, reached into the heart of family life to define its character and social identities. Chancery was therefore linked to and associated with family affairs long before the formation of a Dickensian cultural memory for this court. Research for this article has also revealed that the number and proportion of female litigants acting in the capacity of "mother" actually rose in the late seventeenth century and that the balance shifted toward mother-litigants appearing as defendants. The latter is suggestive of structural changes around the property of children and maternal litigation in this period. The significance of these quantitative and qualitative findings taken together lies in showing that maternity as a legal rhetoric used in pursuit of social justice was one continuous and important component of the institutional discourse of Chancery. Maternal tropes were integral to the doctrinal development of English equity and embedded in its langue and habitus. ${ }^{71}$

\footnotetext{
${ }^{71}$ Mark Fortier, The Culture of Equity in Early Modern England (Aldershot, 2005); Mark Fortier, The Culture of Equity in Restoration and Eighteenth-Century Britain and America (Farnham, 2015); Klinck, Conscience, Equity and the Court of Chancery in Early Modern England; Gary Watt, Equity Stirring: The Story of Justice beyond Law (Oxford, 2009).
} 